\title{
Addressing Reality: A Model for Learner Driven and Standards-Based Internships for Educational Leadership Programs
}

\author{
Gregory C. Geer \\ Coastal Carolina University
}

In many professions, internships apply classroom learning to the actual professional setting with the guidance of mentors. Internships, as a component of education for educational leaders has been roundly criticized. This paper describes the research and design process employed as an internship experience for a new Master's degree program in educational leadership. The result is a flexible, site, and intern specific internship model applying principles of heutagogy as interns learn about Complex Adaptive Systems within schools. Unexpected positive outcomes for interns and the schools they serve are discussed.

Keywords: educational leadership internships, educational leadership education, andragogy, heutagogy, Complex Adaptive Systems (CAS), ELCC standards, complexity theory

\section{INTRODUCTION}

This paper details an internship model for educational leadership programs designed to provide the intern individualized, hands-on, experiential learning opportunities. It allows useful, practical, and readily applied experiences to aspiring building-level leaders' practice as they prepare to enter educational leadership and administration ${ }^{1}$. The model flips the design from a top-down, command and control orientation driven by the academy to a more distributed practitioner focus. It positions the design of activities comprising much of the internship into the hands of the interns and their mentors, the school principal. Although much of the internship design becomes a function of the intern and site supervisor, the term used for the mentor/principal, the university supervisor (professor) guides the process, serves as a resource for both the intern and site supervisor by facilitating the entire internship process. While the design emphasizes the development of leadership skills, there are significant opportunities for activities exercising the management component of administration. Elements cited as useful by the literature and the author's previous research, e.g., in-basket case studies and reflective essays are incorporated into the internship design as well (Anast-May, Buckner. \& Geer (2010); Geer, Anast-May, \& Gurley (2014).

The internship design outlined in this paper informs those charged with designing and revising internship experiences. It is a flexible and learner-friendly framework embracing the self-determined learning theory of heutagogy. Its adaptability extends to the conditions of schools, as explained by complexity and the application of the components of Complex Adaptable Systems (CAS). The design is flexible and readily adapted to various localized environments as well as the specific requirements of external institutions such as state licensing departments, accreditation organizations, or university policies. In the case of the internship described in this paper, those groups included the National Council 
for the Accreditation of Teacher Education (NCATE) ${ }^{2}$ accreditation process (now the auspices of CAEP) as outlined in the Educational Leadership Constituent Council's (ELCC) building-level program standards. Also, the conceptual framework of the college and the licensing requirements for school leaders in the state of South Carolina informed its design.

\section{LITERATURE REVIEW}

\section{Criticism of Educational Leadership Programs and Internships}

The internship component of educational leadership is a paradox. Dating to the 1940s (Chance, 1990; Foster \& Ward, 1998), few in the field of education would argue that it is not a valuable experience (Greenfield, 1975; Milstein et al., 1991; Murphy, 1992, 2006, Skalski et al.; 1987). Literature suggests some benefits accrue to the school district (Daresh, 2004), the mentor sponsoring the intern, as well as the interns themselves (Daresh, 2004; Ehrich, Hansford, \& Tennant, 2004).

Throughout the last half of the twentieth-century school, administrative practices were deeply rooted in the theory and practice of twentieth-century management, leadership, and organization. General criticism of educational leadership programs is widespread through the literature ranging from admissions selectivity (Griffith. Stout, \& Forsyth, McCarthy, 1988), program rigor (Levine, 2005) to resources supporting programs (Murphy, 2002, 2006; Sanders, 2005). These problems are a significant contributor to issues plaguing our schools (Levine, 2005). More specifically, educational leadership programs' internships are criticized as contrived experiences since the interns are usually working full time as teachers or other school-level personnel. These conditions limit candidates' ability to engage in a full time, embedded internship because of professional, personal, and financial constraints. Due to these conditions, the internship experienced by educators earning administrative licensure is profoundly different than the one they experienced as student teachers. Rather than actually performing the job within a school's typical timeframe and daily activities as a student teacher does, the administrative intern is forced to piece together experiences that fit more complex life circumstances associated with already having a full-time job and personal obligations. Without the conditions that support full time, jobembedded internship, these circumstances contribute to cited shortcomings of educational leadership programs (Elmore, 2005; Jackson \& Kelley, 2002; Southern Regional Education Board, 2005; Illinois State Board of Education, 2006).

Other weaknesses of the internship experience are symptomatic of broader issues within educational institutions. Many of today's internships continue to follow a framework emphasizing top-down control of its activities rather than a professional model emulating the environment in which the educational leader operates (Mehta, 2013; Mirci \& Hensley, 2010). For example, traditionally, the internship model employed by some educational leadership programs is a rigidly controlled, top-down function of the university and its faculty. And although programs may alter the activities to reflect contemporary conditions in education, control of the actions comprising the internship are a function of the students' educational leadership programs. Their design promotes the internship's efficiency rather than improved student learning (Creighton, 2002; Dubin, 1987; Fulmer, Muth, \& Reiter, 2004; Milstein, 1990; Murphy, 1982). Rather than embrace the need for innovative educational leadership to deal with the complex issues of contemporary schools and their stakeholders, many educational leadership programs are slowly adapting to the complexity characterizing today's schools for a variety of reasons. As a result, it can be argued that these internships are insensitive to adult learning principles ignoring andragogy and the tenets of constructivist theory.

\section{The Importance of Internships and Quality Mentors}

Further adding to the argument that the internship is paradoxical is the failure to embrace research confirming that a quality internship is a crucial component to adequate educational leadership preparation. For example, Orr and Orephson's research on principal preparation programs theorizes that the internship as integral to preparation programs of educational leadership. In their conceptual framework, the internship is on equal footing with the students' classroom preparation when analyzing the effects of 
quality educational leadership programs (2010). Internships need to emulate the fast-paced, ever-changing environment of the contemporary school with its complex systems influenced by external and internal forces. Too often, conventional internship experiences ignore the unique culture and needs of individual schools and, in turn, the learning needs of interns. And despite a consensus on the importance of internships in the increasing number of educational leadership programs (Milstein, Bobroff, \& Restine, 1991; Skalski, Lohman, Szcepanik, Baratta, Bacilous \& Schulte, 1987), there is little guidance in the literature providing direction as to the types of specific experiences or activities that future educational leaders should have. These conditions underscore the importance of the sponsoring site supervisors at the interns' placement. Quality mentoring during this process is key to a quality internship experience (Anderson, 1989; McKerrow, 1998; Milstein, 1990). And beyond a small stipend or tuition for courses, educational leadership programs ignore incentives for site supervisors. Beyond altruism, what reasons incentivizing mentorship of interns for educational leaders for the already busy school leader? Their professional life is involved and complicated work, why take on the responsibility of an intern? Yet, their role is crucial.

As mentioned previously, for a variety of reasons ranging from cultural to the economic, many educational leadership programs were and continue to be slowly adjusting to the conditions of modern schools (Levine, 2005; McCarthy \& Kuh, 1997, Murphy, Moorman, \& McCarthy, 2008; Pohland \& Carlson, 1993). As a result, internship frameworks within educational administration programs mimic scientific management theories and practices of the last century's industrial world. This orientation towards scientific management resulted in a top-down, bureaucratic checklist approach to internship activities rooted in managerial skills created and managed by the degree-conferring higher education institution. This format mimicked the actual managerial orientation of school districts and schools themselves. Today's and future educational leaders need experiences practicing the ability to operate in a less hierarchical organizational structure recognizing the professionalism of faculty and staff focusing on instructional leadership. The skills to cope and lead within ambiguous, politicized, and complex conditions are essential for contemporary school leaders, including principals (Cunningham \& Sherman, 2008) and, as a result, impact their educational preparation and precisely the subject of this paper. School leaders must be adaptable to ever-changing environments rife with ambiguity.

And although internships are seen as necessary, critics point out that many internship programs still do not offer the experiences that successfully prepare future leaders (Levine, 2005). Darling-Hammond, LaPointe, Meyerson, Orr, Cohen summarize this criticism, concluding that "Efforts to provide field-based practicum experiences do not consistently provide candidates with a sustained, hands-on internship in which they grapple with the real demands of school leadership under the supervision of a well-qualified mentor." (2007, p. 6). This sluggish institutional adaption to the realities of contemporary pressures on school leaders by educational leadership programs is contrary to calls for leaders that can systematically think and act with agility to address the new environment of the information age (Senge, 2006; Wagner, Kegan, Lahey, et al., 2010).

The importance of real-world experiences for future educational leaders must be a high priority and a central focus of principal preparation programs (SREB, 2007). Scholars in the field have emphasized that the engagement with school leadership teams and principals during the internship as indispensable to the socialization process that must occur for administrative leadership capacity building and transformation (Browne-Ferrigno \& Muth, 2004). Further, the quality of the internship experience is seen by students as an indicator of the quality of the educational leadership preparation program (Orr, 2010). Widely researched and accepted is the idea that purposeful engagement in school leadership activities has a positive influence on the ability of principal candidates to later perform administrative roles. (Jean \& Evans, 1995; Milstein \& Krueger, 1997, Restine, Milstein \& Broboff, 1989; Orr \& Orephson, 2010). It follows that well-planned internships will positively influence the likelihood that graduates will become leaders putting their learning into practice (Orr, 2010).

With an increased focus on student achievement in the 1990s, new accountability systems emerged characterizing contemporary educational reform are ubiquitous and call for changes in the preparation of future educational leaders (Levine, 2005; National Commission for the Principalship, 1990; NGA Center 
for Best Practices, 2003). As a result, efforts beginning in the 1990s and continuing today started to seek ways to strengthen the internship programs in educational leadership (Bass, 1990; Foster \& Ward, 1998; Milstein, Broboff \& Restine, 1991). A vital component of the reform movement directly related to the administrative internship is, "greater emphasis on making the knowledge-to-practice connections providing students opportunities to work on real-world problems in the most authentic settings possible under the guidance of university faculty experienced practitioners." (Cunningham, 2007, p.3).

In addition to the call for connections of theory to practice, researchers have challenged the quality of many administrative intern programs, and proposed changes they believe will strengthen the professional preparation process (Darling-Hammond, et al., 2007; Levine, 2005). Researchers concluded that the internship should allow the candidate to translate theoretical concepts into practice and learn from the consequences (LaPlant, 1988; Milstein et al. 1991; Wilmore, 2002). Through this practice, the internship can change candidates' perceptions about the principalship (White \& Crow, 1993) and assist in developing essential skills and professional dispositions crucial to success as an educational leader (Cordeiro \& Smith-Sloan, 1995). They summarize the experiences interns should have as:

future principals need to get hands-on experience by working with school leadership teams as they investigate achievement gaps and work to solve them. The aspiring leaders would get practice in planning and initiate changes in curricula, teaching practices, student support services and school organization. By working on real problems and witnessing the results of strategic interventions, they would acquire the practical knowledge and understanding that are impossible to duplicate in lecture courses. (p. 7)

Research suggests that clinical activities, led by practicing administrators alone, are not well coordinated and integrated into preparation programs (Brown-Ferrigno \& Muth, 2004; Sherman, 2005; Elmore, 2006; Jackson \& Kelley, 2002; Southern Regional Education Board, 2005; Illinois State Board of Education, 2006).

Cunningham and Sherman succinctly give us directions for addressing the weaknesses in the administrative internship experience:

it is difficult to frame internship opportunities that have enough depth to cover all critical aspects, this is indeed the challenge we face as preparers of future educational leaders if we want to meet the new demands of the profession. [Additionally, they recommended that] In the age of accountability, an emphasis must be placed on tasks that facilitate instructional leadership, school improvement, and student achievement - historically overlooked and nonexistent aspects of the internship. (2008, p. 310)

\section{THE CONTEXT}

\section{Design and Internship}

As one of two faculty hired at the inauguration of the M.Ed. in Educational Leadership program at a master's level university during the fall of 2009, the author was responsible for designing and implementing the internship component of the program. The design of the internship took shape over the next $1 \frac{1}{2}$ years as the first cohort of students proceeded with their coursework through the program's curricular sequence.

Before designing the internship, the author spent a year reviewing research on educational leadership programs and their internships and, as stated previously, found it rife with criticism. Internet searches of other higher education institutions yielded information on their internships. Also, two professors of educational leadership at other universities graciously forwarded materials used in their programs. Further grounding this study is the author's experience as a building principal, school district superintendent, and was a site supervisor for both aspiring and practicing principals both informally and during internships. 
The literature review and the author's own experiences as an educational leadership student and intern and as a PK-12 administrator also informed the internship design.

Another critical factor in the internship's design was the need to address accreditation requirements for state licensing of the program's candidates. This requirement was accomplished as the author developed a thorough understanding of the ELCC standards. These standards also formed the basis of the exam students were required to pass as part of the licensing requirements to become a school administrator. During the same year, the author was part of a research team that was interviewing principals in the region on what they deemed necessary for administrative internships. This research is detailed in the Anast-May, Buckner, and Geer (2010) paper and caused the author to contemplate ways to incorporate into the internship the information and themes from these interviews. Within these parameters, a design emerged for a markedly different type of internship for aspiring educational leaders.

\section{A KEY TO RELEVANCY}

\section{Collaboration with Regional School Districts}

When universities and school districts collaborate, as they did in the case examined in this paper, internship activities can be designed that merge theory and practice into practical, informative experiences. School principals, who later served as internship site supervisors, reinforced this thinking as information from structured interviews with them were used to design the internship model. Structured interviews with 47 regional principals strongly influencing the internship design. They stressed the need for learning activities that were realistic relative to principals' work that was flexible and adaptable to the schools' circumstances (Anast May et al., 2010; Geer et al., 2014). The Geer et al. (2014) study confirmed the efficacy of allowing site supervisors to play a significant role in designing relevant internship activities. It found that principals interviewed in the Anast May et al. study who were subsequently acting in the role of site supervisors did, as reported by interns, facilitate the design of internship activities for areas they deemed necessary for the interns to experience (2010).

Further, the Southern Regional Education Board (2005) report further comments on the importance university/school district partnerships by contending that quality university-based internship programs must have a "collaboration between the university and a school district that anchors internship activities in real-world problems principals face and provides for appropriate structure and support of learning experiences." (p.7). Cunningham \& Sherman (2008) specifically comment on the importance of this type of partnership by pointing out that "the emphasis on contextual relevant instructional leadership is best achieved through well-designed internship experiences with collaboration between universities and school districts." (p. 311).

\section{CONCEPTUAL FRAMEWORK}

The conceptual framework for the internship design emerged from the context described above and the realities facing the educational leader. Inarguably, school leaders daily face situations characterized by a myriad of ill-structured, loosely-coupled, and complex issues (Davis \& Sumara, 2008; Jackson \& Kelley, 2002; Morrison, 2010; Wieck, 1976, Leithwood, 1995). These complex learning situations are appropriately addressed by adult self-directed learning, a process termed as heutagogy (Bhoyrub, Hurley, Neilson, Ramsay \& Smith, 2010; Hase \& Kenyon, 2007; Hase, 2008). The schematic below illustrates the research's conceptual framework emerging from the interactions and synthesis of heutagogy and complexity theory bounded by the ELCC standards resulting at their intersection. This area of intersection is the subject of this paper, internships for aspiring building-level school administrators.

The following sections detail the three defining components of the conceptual framework of the internship model supported by pertinent literature. As portrayed in Figure 1, the internship is formed within the intersection of these three components, heutagogy, complexity theory, and the ELLCC standards. 


\section{FIGURE 1 \\ CONCEPTUAL FRAMEWORK OF THE INTERNSHIP DESIGN}

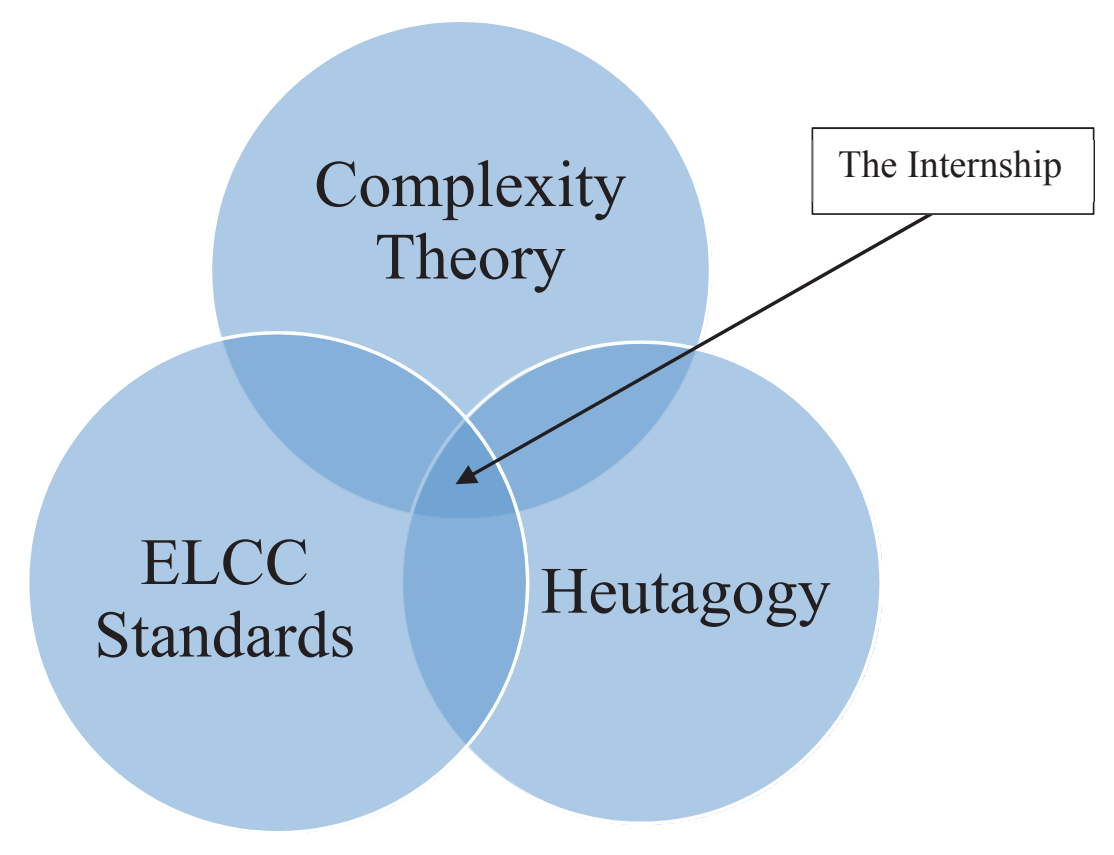

\section{Three Components of the Conceptual Framework}

\section{Component One: Heautagogy as a Tool for Teaching in Complex Settings}

To address the complex responsibilities of school administrators within a learning experience is not an easy task. Supporting this approach to the educational leadership curriculum and explicitly, its internship is supported by the widely accepted theory that adult learning, termed andragogy, is significantly different from children's education (pedagogy). Theorist Malcolm Knowles summarizes the six learning principles of adult learning by stating that adults:

1. are internally motivated and self-directed,

2. bring life experiences and knowledge to the learning experiences,

3. are goal-oriented,

4. want to be taught relevant information,

5. are practical, and,

6. like to be respected (Knowles \& Holton, 2005).

Knowles' theory serves as the foundation for Hase and Kenyon's work on heutagogy. They define heutagogy as a theory, "concerned with learner-centered learning that sees the learner as the major agent in their learning, which occurs a result of personal experience." (Hase \& Kenyon, 2007, p. 112). Hase and Kenyon address what they argue is a limitation of andragogy because it is a teacher-driven process. Whereas, the learning process in heutagogy is learner-driven.

Furthermore, Hase and Kenyon support heutagogy as means for the student to move from knowledge and competency to the goal of becoming capable. They contend that people are capable when they can use competencies in novel situations. In other words, capable people can deal with the unknown and complicated. Hase and Kenyon further argue that heutagogy is a child of complexity theory (Hase \& Kenyon, 2007) and, as such, aligns the internship design with the realities of contemporary and future educational systems at all levels. Since schools are complex entities, heutagogy is appropriate when applied to the education of educational administrators, and its internships.

With the leader responsible for everything that occurs in a school (the principal) or school system (the superintendent), these leaders must use their knowledge and competencies in the complicated and messy 
world of education in a measured, thoughtful way. What curriculum or checklist can capture the myriad of variables educational leaders may encounter in their daily practice? These limitations to traditional internships are among the causes of criticism of educational leadership programs. How can we educate school leaders, so they learn to deal with the complex systems they will lead? The workplace challenges of school life are increasingly difficult for the educational leadership faculty to replicate in the classroom or predetermine as concrete learning activities before the placement of interns within the unique environment of each school. However, when students design their own field experience while collaborating with the site and university supervisors, this complexity is framed into learning experience aimed at attaining capability. That is, heutagogy facilitates the design of meaningful internships' activities essential for those learning to lead schools. Additionally, it takes advantage of the teachable moments that readily occur within schools. Again, this idea is well articulated by Bhoyrub et al. (2010) when discussing another complex profession, nursing:

Additionally, the construct of complexity theory has a powerful resonance with practice learning environments and hence the challenges facing all educative stakeholders. Learner capability, central to heutagogy, also has significant resonance with the aspirations of nurse education further indicating potential application. Heutagogy, therefore, is a potential-packed approach to clinical learning that provides an alternative lens from which to both view and construct practice-based educational components. (p.385)

Hase summarizes why, within the educational curriculum of school leadership and administration, the tenets of heutagogy, is an agile and adaptable response to address the complexity of the environment of school leadership. Referencing heutagogy, he writes:

Based on humanistic and constructivist ideas heutagogy is meant to take into account the fact that learning takes place irrespective of the intention to create learning and that there is a critical difference between knowledge and learning. Heutagogy is concerned with helping people and organizations develop the elements of capability. (2002, n.d.)

Component Two: Complexity Theory as Expressed in Complex Adaptive Systems (CAS)

The application of complexity theory to social science is maturing. When applied to human systems, complexity theory is called Complex Adaptive Systems (CAS) or complex adaptive human systems (Senge, 2006). Defined as a group of parts that interact in meaningful ways to achieve a shared purpose, it aptly describes schools as an organization. With what seems like uncountable variables with confounding and constantly morphing circumstances, schools are loosely coupled organizations that are in constant flux. For the educational leadership student whose view of schools is evolving from that of the teacher to the school leader, complexity theory is useful for thinking about all of the different situations that the typical school day brings to principals and their support teams. Biesta \& Osberg (2010) connects complexity theory to education by writing:

This is also the case in the field of education where complexity has provided a language for articulating the fact that educational processes and practices tend to be characterised by nonlinearity and unpredictability and by a fundamental gap between "input" (teaching, curriculum, pedagogy) and "output" (learning). (p. 2)

The linkage between complexity theory, heutagogy, and clinical learning experience is articulated by Bhoyrub et al. (2010):

Additionally, the construct of complexity theory has a powerful resonance with practice learning environments and hence the challenges facing all educative stakeholders. 
Learner capability, central to heutagogy, also has significant resonance with the aspirations of nurse education further indicating potential application. Heutagogy, therefore, is a potential-packed approach to clinical learning that provides an alternative lens from which to both view and construct practice-based educational components. (p.385)

Although this quotation deals with nursing education, its application to the education of school administrators is appropriate because of the complexities characteristic of both professions.

To further illustrate the application of complexity theory to school, indulge in this thought experiment. Project yourself into a contemporary American PK-12 school building. It doesn't matter if it is an elementary, middle, or high school and then take a bird's eye view of what is happening. Imagine busses and parents as they drop off students, or later the students themselves drive a vehicle (by the way, the root of many issues in high schools). A work crew is on the roof, fixing a leak that is dripping onto the gymnasium floor, which has buckled and is unusable. Parents are lined up in the office, leaving money from a student government fundraiser. A teacher is bringing two boys to the nurse since they were involved in a playground squabble. A mother is in the principal's office complaining about her child's math teacher. On the principal's desk are several budget documents that are due to the central office by the end of the day and need finalization. In the adjoining conference room, the Committee on Special Education (CSE) is holding an annual review of a student's progress on the year's learning goals and agreeing on new ones. The assistant principal and school counselors are busy going from classroom to classroom distributing standardized tests for today's administration. Students are coming back from getting their breakfast and attending a before-school tutoring program for at-risk students. The teachers are finalizing plans for the day, a technician is fixing the copier in the office, the custodian makes a sweep of the halls, lunch preparation begins, and students gather to deliver the morning news from the school's television studio. And think - the school day has not even started yet with its primary function of teaching and learning. If this does not describe complexity, what does? Keep in mind that the principal is responsible for all of this. CAS gives leaders a way to observe, analyze, and act within such an environment.

\section{Component Three: Boundaries Derived from Professional Standards}

The ELCC standards are widely "used as lenses through which to gauge candidate performance, identify areas for improvement, and introduce reasonable curricular changes." (Kersten, White, \& Trybus, 2010, p.6). Based upon a synthesis of research on educational leadership (Young \& Mawhinney, 2012), the ELCC standards serve this internship model as a framework giving it a modicum of standardization and uniformity between candidates' experiences. The internship spans two semesters, and projects address all seven ELCC standards over the 300 hours of two internships. This design principle gives a common framework to the internship experiences within the inherent variability resulting from heutigogical principles of self-directed learning. It also reinforces the ELCC standards' concepts, which throughout the degree program provide a foundation for curricula and result in the development of a common lexicon between students, professors, and site supervisors as they review plans for the internships' projects.

\section{A SYNTHESIS BUILDS A NEW INTERNSHIP STRUCTURE}

Over a year, the goal of formulating a new internship design recognizing the needs of the candidates and the complexity of school administration bounded by accreditation standards emerged and evolved. The literature of heutagogy, complexity theory, discussions, and research with colleagues, much reflection, and informed many design drafts. Rather than replicate a checklist of prescribed experiences, operationalizing this internship design through collaborative efforts evolved among the intern, the site supervisor who generally is the school principal, and the university faculty member called the university supervisor. 
The overarching design principle of the internships is tripartite. It couples the individual learning and experiential needs of the intern with the needs of the site of the internship. This process is monitored and adjusted by the university supervisor to meet accreditation standards (See Figure 3). The results are internship experiences characterized by flexibility and adaptability to variables, including differences in the conditions of the interns' school placements and the skills and personalities of the interns and supervisors. The internship activities afford hands-on, experiential learning opportunities providing useful, practical, and readily applied experiences to aspiring principals' practice as they prepared to enter the field of educational leadership and administration.

A significant challenge was operationalizing these characteristics of flexibility and realism into the internship's design while framing it with structures providing a modicum of uniformity among internship sites, site supervisors, intern needs, and activities. To address all of these systemic variables was challenging. One useful tool assisted in bringing coherence and structure to the internship occurred when the university faculty and select principals formed a Principals' Advisory Council. This group meets several times a year and continually informs the faculty of the educational leadership program of contemporary needs and practices. This collaboration is a characteristic of effective educational leadership programs (Goldring \& Sims, 2005) that provides an ongoing university/district dialogue informing the educational leadership program and, consequently, the internship. A similar group composed of students also meets with faculty on program matters, which also provides suggestions for improving the internship.

The internships' flexibility and adaptability were the functions of the design of the internship activities. Guiding the basis for these activities were the interns' self-identified growth areas within educational leadership and administration, which employs the process depicted in Figure 3 below. A document fostering reflection on growth areas was administered to interns during the first site placement with its results used again in the second internship placement. Through this reflective exercise, the interns had a reference point for discussing and collaboratively designing with their site supervisors various activities relevant for the development of the interns' skills set. In the case of the major 30-hour projects (PGPs), the university supervisors provided input into the project's initial planning (PGPP). The model also takes into account macro forces external to the internship, such as changing political realities acting upon the educational environment and micro-influencers specific to the site of the internship.

Figure 2 shows the heutagogical design process integral to the internships' project construction that provided flexibility and adaptability. 
FIGURE 2

THE HEUTAGOGICAL DESIGN PROCESS

\section{HEUTAGOGIC DESIGN PROCESS}

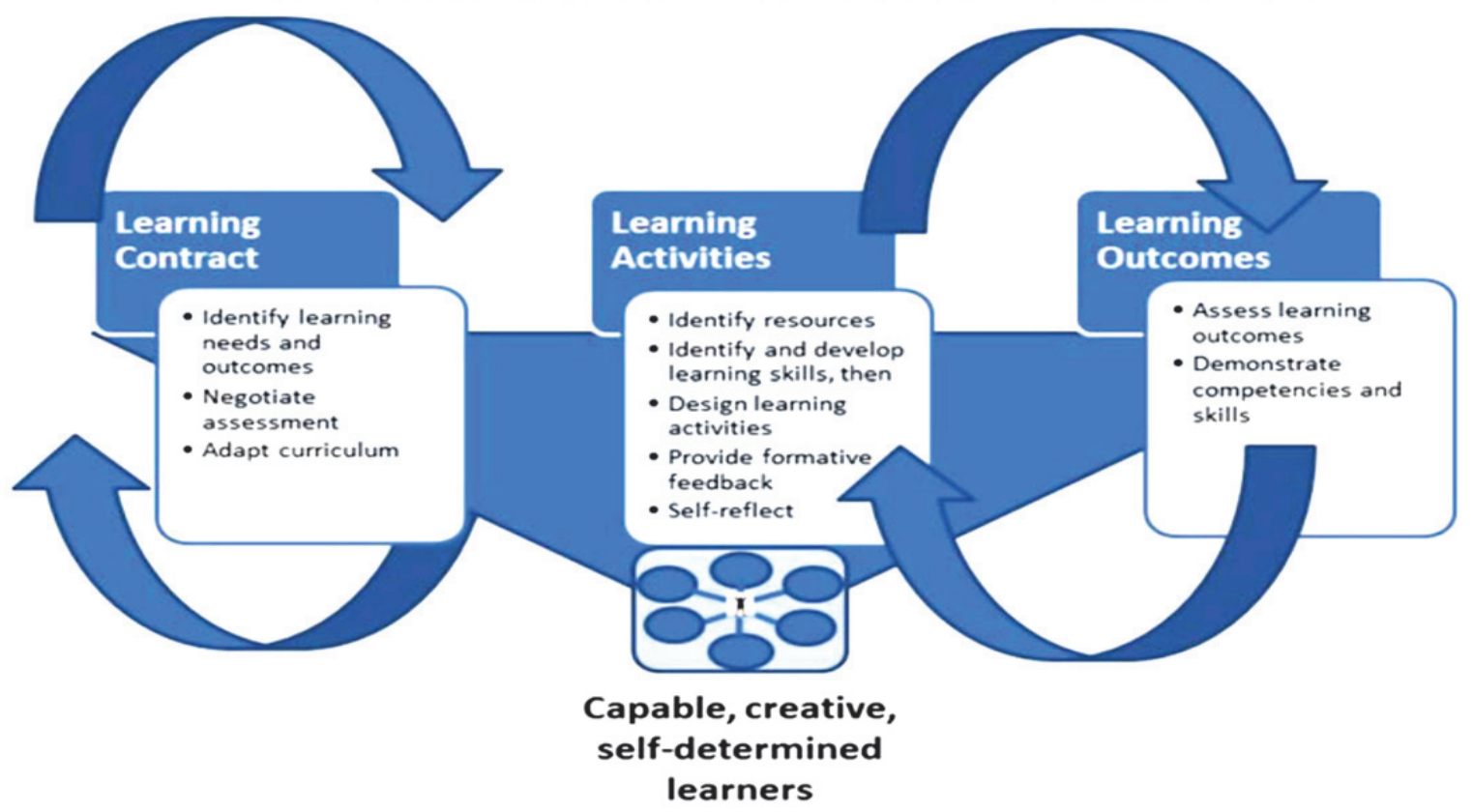

(Blaschke \& Hase: 2015, p.30)

In addition to the application of the process depicted in Figure 2, the conceptual framework in Figure 1, coupled with the author's professional experiences as both an intern and site supervisor also informed the internship model. A synthesis of the research on principal preparation, heutagogy, complexity theory, and administrative internships influenced drafts of the new internship structure. Placing focus on both the needs of the intern and the site of the intern placement became central tenets of this internship design. Furthermore, complicating the process was the need to build structure, ensuring quality internship experiences with the need for flexibility in meeting the interns' learning and the sites' conditions. Throughout the research, design, pilot phases, and revisions resulting from candidate feedback, requirements for NCATE accreditation were regularly reviewed and addressed in the internships' designs and assessments.

The following design parameters for the internship emerged from the candidates' learning needs, the practicalities of the candidates' circumstances, the author's research, and accreditation requirements:

1) The internship would consist of two separate sites, each being 150-hour placements for a total of 300 hours over two semesters. Ideally, one internship is at the intern's school of employment and one at another school.

2) The internship's hands-on activities take two forms.

a. At each of the two sites, three of the projects named Building Action Plans (BAP) were each 10 hours in duration for a total of 30 hours.

b. Three projects at each of the sites were Professional Growth Plan (PGP) and were each 30 hours in length for a cumulative 90 hours.

3) Each placement also had five in-basket case studies posted in the online course management system (CMS).

4) The interns kept a $\log$ /journal that documented their activities, the amount of time they were spending on the internship, cross-referenced their documentation with various standards and 
wrote reflectively about their experiences. Details about these and other components of the internship follow.

\section{MAJOR DESIGN COMPONENTS OF THE INTERNSHIP}

\section{Building Action Plans (BAP)}

During his career as a principal and school superintendent, the author of this paper served as a site supervisor for several interns. From those experiences, he knew that beyond altruism, one of the more selfish reasons for supervising interns was that the school would have another set of hands to work on projects they might never get to or were too time-consuming. An intern could be a resource for dealing with these circumstances through BAP activities. These projects are a minimum of 10 hours in duration, do not require the university supervisor's approval, and give the site supervisors the use of the intern as a resource for their school and often are management, process, and procedure-oriented. This collaboration between the site supervisor and the intern resulted in jointly built projects that were needed by the school. Some examples of BAPs include the organizing of the distribution of textbooks, representing the school on school improvement councils, soliciting local businesses for contest prizes, designing and producing brochures for parents about different school programs, supervising extracurricular events, and other activities that school administrators do as routine matters. The completed plans are submitted through the online CMS. The university supervisor assesses the completed BAP activities, the interns' reflective essay, and feedback returned to the intern.

\section{Professional Growth Plans (PGP)}

Professional Growth Plans (PGP) are lengthier and more complicated than the BAPs. Consisting of a minimum duration of 30 hours of work, the interns in these projects must demonstrate leadership within the minimum of two activities comprising each PGP. Providing structure to the internships' activities and guiding the site supervisor and intern, each PGP must address one of the six ELCC Standards for Building Level Leadership. Designed in collaboration with their site supervisor, each PGP plan is submitted to the university supervisor through the CMS. The university supervisor reviews the plan, and if satisfied with its rigor and that it provides the intern with a worthwhile learning experience addressing one of the ELCC standards, approval or suggestions for revision are sent through the CMS.

Figure 3 visually portrays the interactions of the intern, site supervisor, and university supervisor as inputs in the internship model. This process results in a licensed and skilled school administrator through the creation of internship activities and the candidates' previous coursework. 
FIGURE 3

SCHEMATIC OF THE INTERNSHIP MODELS INPUTS, PROCESSING, AND OUTCOMES

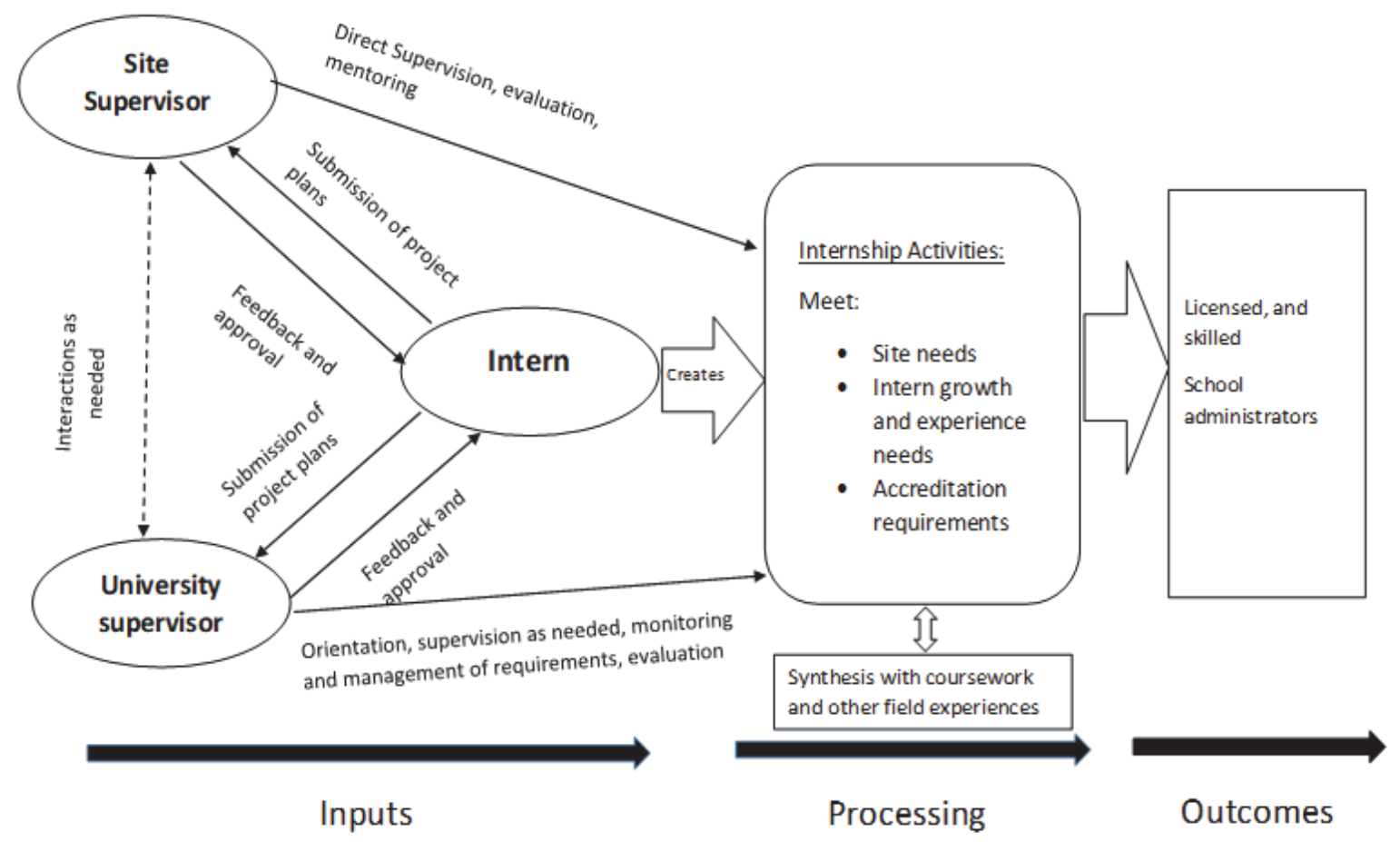

Some examples of PGPs include developing and leading professional development, participating in interviews for hiring various personnel, creating and leading events, and leading annual reviews of special education Individualized Education Plans (IEP).

\section{REFLECTIVE PROCESSING}

Reflection is a necessary learning process as an exercise in metacognition, creating learning and, ultimately, capability. It is integral to adult learning. By practicing reflection, students review and eventually synthesize learning and even change previous practices and viewpoints (Kolb \& Kolb, 2005; Garrison, 2006). Throughout the internship activities in BAPs, PGPs, in-basket activities, and journaling, the interns reflect upon their own experiences. The CMS is used by the interns to submit their written reflections and, subsequently, the university supervisor to provide feedback and grades. This process often provides data for accreditation. As part of the BAP, PGP, and journaling activities, interns correlate their observations and reflections with the appropriate ELCC standards. Their written reflections serve as a significant component of interactions with their university supervisor.

\section{In-Basket Activities}

When the author was researching the Anast-May et al. (2010) study, many of the interviewed principals repeatedly mentioned that in-basket activities about realistic school-based situations as a valuable activity from their internships. To address the principals' input, these activities became part of the internship design and delivered through the CMS.

During each semester of the internship, interns write responses to prompts for four hypothetical situations, and in the second internship, two career development questions. Eight of these hypothetical, case-study exercises require the interns to solicit input from their site supervisors on their response to situations that might occur in a school. Examples of these case studies include various situations with personnel, professional development strategies, sub-standard teaching performance, and philosophical 
differences with a superior. Another example of other in-basket discussions is that during the first placement, interns write a reflection on their leadership style. In the second placement, one in-basket has the interns map out a career ladder as an educational leader. The interns' draft responses to these situations are reviewed with the site supervisor, and their input incorporated into the intern's responses. The responses must have a citation from literature to support the interns' answers, and interns also comment on two of their classmates' posts on the electronic discussion areas in the CMS. Additionally, interns receive feedback and grades on their work from their university supervisor.

\section{Other Activities Comprising the Internship}

Growth Inventory

Early in the first internship placement, the interns reflect upon and ranked by their level of expertise in eleven administrative areas. Students focus on the areas that they rate lowest when constructing internship projects.

\section{School Profile}

For each placement, interns create a demographic, student achievement, and school culture profile. This activity documents accreditation requirements for diverse settings for interns and also familiarizes them with their site.

\section{Comprehensive Exam}

Several weeks into the first internship placement, students access the comprehensive written exam, which is one of the program's mandated NCATE (now CAEP) ELCC Specialized Professional Association (SPA) assessments. They have until the end of the semester to complete and this open book exam. Using their knowledge and references, they construct responses to six questions, one on each of the ELCC SPA standards. These are corrected and feedback provided by the students' university supervisor and assessed in the accreditation software.

\section{Portfolio Presentation}

During the second internship placement, students create a portfolio that represents their best work connected to each of the six ELCC standards, which is in the vast majority of the time comprised of their internship projects. This portfolio is placed into accreditation related software and assessed by the university supervisor. The second internship culminates with a discussion of the portfolio between the intern and the university supervisor. This discussion often is emotional as students reflect on their journey through the program and the depth of their learning and experiences.

\section{Assessment of Interns}

The assessment of the interns' performance is two-pronged. The site supervisor formatively assesses the BAP, PGP, and eight of ten in-basket activities. The intern certifies that the site supervisor has seen and approves the submission of these activities by submitting them to the CMS. The university supervisor reviews, make suggestions for alterations to projects and ultimately approves PGPs. The site supervisor provides a summative assessment of the interns' overall performance. The university supervisor summative assesses interns on the comprehensive exam in the first internship, the portfolio in the second internship, and their projects, log/journal, and attending reflective exercises assigned to these components.

\section{METHOD OF DETERMINING THE EFFICACY OF THE INTERNSHIP DESIGN}

\section{The Survey}

Using the theoretical framework as a foundation, a survey consisting of 34 questions was developed. The survey included 20 Likert-type questions and 14 open-ended response questions. In order to gain insight into the interns' perspectives on the internship, initial survey questions gathered demographic information and perceptions about the structure of the internship (i.e., internship duration and settings), 
interns' career aspirations in educational leadership, and interns' perceptions of the efficacy of the internship in preparing them for school leadership. Participants responded to a four-point, Likert-type scale providing options as follows: $4=$ Frequent Involvement, $3=$ Some Involvement, $2=$ Limited Involvement and, 1 = No Involvement. Interspersed between the Likert-type scale questions was a third section of the survey consisting of open-ended response questions allowing participants to enter text describing the specific activities and experiences they gained regarding the three themes and the perceived impact the experiences had in preparing them as future school leaders.

After review and approval by the University's Internal Review Board (IRB), the survey was loaded into a commercial software product designed for anonymous administration and convenient data collection and disaggregation. A website link to the questionnaire was disseminated electronically to all educational leadership students who were completing their second semester of internship placement. Students had approximately two weeks to complete the questionnaire. Responses to this administration were coded and entered into the Statistical Package for the Social Sciences (SPSS) software. A split-half test for the reliability of the instrument was conducted. The resulting Guttman Split-Half Coefficient for instrument reliability for the teacher assessment survey was .892, well above the accepted coefficient level of .700 (Mason and Bramble, 1997, p. 276). Survey results were compiled using the software tools that summarized the questionnaire's Likert-type scaled responses into bar graphs and compiled narrative responses to each question. Responses to the Likert-type scaled questions were analyzed using descriptive statistics to report on the magnitude of agreement among respondents on the scale category. Answers to the open-ended type questions provided additional anecdotal evidence relative to each of the research questions. Answers to the survey's Likert scale categories were often combined to understand the interns' perspectives better. This category combination is an accepted manipulation of the Likert scales as long as the items combined have a single common factor (Lester \& Bishop, 2000).

\section{DISCUSSION}

\section{Findings}

Beginning in 2011, when the first cohort of the M.Ed. program became interns through 2017, a total of 170 interns were anonymously surveyed about their internship experiences at the end of the second semester's internship activities through a commercial software product. Seventy percent of the respondents were female, and 30 percent were male. Ninety-one percent were teachers. In general, interns were positive about their experiences and felt that the internship prepared them to assume educational leadership positions. Table 1 summarizes interns' perceptions of the internship derived from the author's database of responses from the Survey of Interns conducted 2011-2017. 
Interns' Perspectives from Survey

TABLE 1

SELECTED FINDINGS FROM GEER'S SURVEY OF INTERNS ON THE INTERNSHIP $(n=170)$

\begin{tabular}{|c|c|}
\hline $\begin{array}{l}\text { Question } 7 \text { Please comment on your opinion on the length of } \\
\text { the administrative internship. } \\
\text { Answered: } 170 \text { Skipped: } 0\end{array}$ & $\begin{array}{l}72 \% \text { report that the internship } \\
\text { length was appropriate }\end{array}$ \\
\hline $\begin{array}{l}\text { Question } 8 \text { Please comment on your opinion of the settings for } \\
\text { your internship experience. } \\
\text { Answered: } 167 \text { Skipped: } 3\end{array}$ & $\begin{array}{l}70 \% \text { report that they preferred } \\
\text { two different sites for their } \\
\text { internship }\end{array}$ \\
\hline $\begin{array}{l}\text { Question } 10 \text { Overall, how would you rate the practical value of } \\
\text { your administrative internship experience in preparing you to } \\
\text { assume a leadership position? }\end{array}$ & $\begin{array}{l}80 \% \text { rate the internship as making } \\
\text { them feel well prepared for a } \\
\text { leadership position. Another } 18 \% \\
\text { felt "somewhat prepared. }\end{array}$ \\
\hline $\begin{array}{l}\text { Question } 11 \text { To what extent were you involved in planning and } \\
\text { leading change in curriculum and instruction? } \\
\text { Answered: } 165 \text { Skipped: } 5\end{array}$ & $\begin{array}{l}45 \% \text { report frequent involvement } \\
41 \% \text { report some involvement. }\end{array}$ \\
\hline $\begin{array}{l}\text { Question } 13 \text { Please describe your leadership experiences in } \\
\text { planning and leading change for teachers and students? (For } \\
\text { example: changes in instructional practice, scheduling, } \\
\text { curriculum programs, student discipline.) } \\
\text { Answered: } 140 \text { Skipped: } 30\end{array}$ & $\begin{array}{l}66 \% \text { felt very well prepared } \\
33 \% \text { felt somewhat prepared }\end{array}$ \\
\hline $\begin{array}{l}\text { Question } 16 \text { To what extent were you involved in leading or } \\
\text { supporting activities to nurture a positive culture for learning? } \\
\text { Answered: } 161 \text { Skipped: } 9\end{array}$ & $\begin{array}{l}61 \% \text { had frequent involvement } \\
31 \% \text { had some involvement }\end{array}$ \\
\hline $\begin{array}{l}\text { Question } 18 \text { To what extent have activities in leading or } \\
\text { supporting a positive culture for learning helped prepare you to } \\
\text { assume a future role in educational leadership? } \\
\text { Answered: } 160 \text { Skipped: } 10\end{array}$ & $\begin{array}{l}73 \% \text { felt very well prepared } \\
25 \% \text { felt somewhat prepared }\end{array}$ \\
\hline $\begin{array}{l}\text { Question } 20 \text { To what extent were you involved in business and } \\
\text { community partnerships? } \\
\text { Answered: } 160 \text { Skipped: } 10\end{array}$ & $\begin{array}{l}37 \% \text { had frequent involvement } \\
43 \% \text { had some involvement }\end{array}$ \\
\hline $\begin{array}{l}\text { Question } 22 \text { To what extent were you involved in activities } \\
\text { promoting parent Involvement? } \\
\text { Answered: } 160 \text { Skipped: } 10\end{array}$ & $\begin{array}{l}52 \% \text { had frequent involvement } \\
36 \% \text { had some involvement }\end{array}$ \\
\hline $\begin{array}{l}\text { Question } 24 \text { To what extent were you involved in using data to } \\
\text { support continuous improvement }\end{array}$ & $\begin{array}{l}55 \% \text { had frequent involvement } \\
39 \% \text { had some involvement } \\
3 \% \text { had no involvement }\end{array}$ \\
\hline $\begin{array}{l}\text { Question } 38 \text { Rate your level of agreement with the statement: I } \\
\text { think being able to construct projects is an important learning } \\
\text { tool. } \\
\text { Answered: } 102 \text { Skipped: } 68\end{array}$ & $\begin{array}{l}89 \% \text { agreed or strongly agreed } \\
\text { with the statement }\end{array}$ \\
\hline
\end{tabular}

\section{Other Experience-base Considerations}

Piloting Is Important

When the internship was in its design phase, five students volunteered to pilot its format. This pilot program gave opportunities to implement the internship and beta test its curriculum, assessment, instructional components, and technical requirements. The interns in the pilot program gave lots of 
suggestions to make the programming more relevant and streamline processes and paperwork. Site supervisors were surveyed and suggested improvements to the internship process and procedures.

\section{Be Open to Feedback from the Field}

By seeking feedback from interns and site supervisors, valuable ideas implementing revisions of the internship were often through surveys, site visits, and the program's two advisory committees, one comprised of principals and the other students. For example, after implementing the internship, an alteration to the project's 10-hour projects occurred. Originally these projects called BAPs (Building Action Projects) had to be connected to one of the six ELCC standards and approved by the university supervisor. After the first full cohort of students went through the internship feedback from interns and the site supervisors led to the removal of this requirement for BAPs as redundant and time-consuming.

\section{Use Feedback to Make Improvements}

Over time the effectiveness and practicality of some constraints became apparent. With university faculty unavailable until the start of the university's semester, interns could not work during the summer. Many interns expressed the desire and need to work on internships during the summer. To address these issues, the BAPs were no longer required to be tied to the ELCC standards and did not need approval from the university supervisor. University supervisors could still provide ideas and input, but the direct design of the BAPs became the purview of the site supervisor in the intern. As a result, interns could complete up to 30 hours of their internship experience during the summer using the BAP projects, which exposed them to all of the activities occurring at a school site during this time.

Importance of Clarity in the CMS and Internship Handbook

Precision and clarity in both the CMS and the internship handbook facilitate success for everyone involved in the internship. Candidates provide the university supervisor with any issues with these two critical tools of the experience. The university supervisor then addresses glitches or problems with directions, processes, or implementation. Email posted to the CMS is a tool for dealing with issues and general announcements. These are consistently reviewed and revised as needed.

\section{Anecdotal Impressions from the Field}

Since the inception of the university's educational leadership program, the author of this paper served as a university supervisor within this internship design. Site supervisors often remark about the positive differences between their experiences during their administrative internships and this model. They also report on the efficacy of the internship projects and the value of the work the interns do for them and their schools.

\section{Unforeseen Outcomes}

Several unforeseen outcomes resulted from the internship design. For instance, depending on the socio-economic conditions of the school, the internship funneled human capital to more impoverished schools. As one elementary school principal in a rural school system with limited administrative support stated, "Send me more. The interns that I've had (mentions three names of students from the program) have allowed me to get things done that I wouldn't have ordinarily. They get to see all of the small stuff that goes into the big workings." A high school principal stated, "This gave the intern an opportunity to see the real workings of the job. It was much better than pulling the fire alarm and finishing a checklist like I had to do." (Personal correspondence, February 24, 2014) Repeatedly during the author's visits to schools, comments on the depth of the internship experiences and how much they had learned came from interns, often with their site supervisors present.

\section{Familiarity Builds Efficiency and Efficacy}

Over the first eight years of the M.Ed. in Educational Leadership existence, four iterations of the internships were implemented. Many of the site supervisors have mentored several interns. Additionally, 
several program graduates have assumed principal and assistant principal positions and assumed or assisted with the site supervisor's role. This personal experience with the philosophy and structure of the internship results in its smooth implementation and quality of the internship projects.

\section{Vertical and Horizontal Integration of Good Practices}

A component of the internship that influences its overall efficacy is that interns have two different school sites as placements as required by ELCC Building-level Standard 7.0. These placements resulted in the cross-pollination of ideas and shared practices between school sites. When correctly structured and cultivated, the interactions between the intern and the internship site's personnel can lead to the vertical and horizontal articulation of curriculum, instruction, assessment, professional development, and managerial practices between schools. For instance, an intern who teaches at the high school level placed at a one of the high school's feeder middle school and, through the internship work, creates mechanisms that link the two schools - vertical articulation. Interns may see or experience good ideas from other schools of the same level where they teach, vis 'a vis a middle school practice they bring back to their schools. Conversely, interns shared good practices from their home school with the site schools where they are interning. When the internship is working well, good practices are leveraged throughout schools in districts hosting interns from this model.

University faculty who act in the role of the university internship supervisors encouraged students to experience different school levels than the ones they were currently working. By doing this, interns accrued different experiences that may increase their marketability as educational leaders when making a career move into administration. These placements exposed the interns to different-aged students and unique cultures inherent in elementary schools versus middle schools versus high schools. As interns functioned in different grade levels other than their current positions as teachers, they were exposed to different ideas, attitudes, and methods. They saw firsthand the varying developmental needs of students, the outlook and involvement of parents, varying master schedules, and the list of differences by school level or location goes on and on.

\section{LIMITATIONS}

The complexity of the internship model needs to be exercised with fidelity to expect similar results. This model grew out of the needs of a new program. To generalize its application to established educational leadership programs may influence outcomes. For example, the program faculty must be willing to become facilitators of the programming rather than its primary driver, the sage on the stage model. Essentially, control is flipped from the professor to the site supervisor and intern. This structure is a much different model for the internship than many parties have experienced. The ability to distribute control of the internship design to the intern and site supervisor may influence outcomes.

\section{CONCLUSIONS}

The author's research on andragogy and complex adaptive systems led to the works on heutagogy, and this synthesis resulted in the focus of this paper, an internship design recognizing reality. That is, the model addresses the realities of the needs of adult learners within the context of professional and personal constraints while addressing the site supervisors' needs and requests. Furthermore, the internships' design embraces the complexity of school administration and the variables associated with the program's accreditation obligations. The result has been a positive one according to data from the interns and site supervisors (Geer, G., Anast-May, L. \& Gurley, D.K., 2014), NCATE accreditation review, and an invitation to present the model to other higher education institutions by the South Carolina Committee on Higher Education. It is conceivable that the central tenets of this internship model are adaptable to other disciplines, especially those with accreditation requirements. 


\section{RECOMMENDATIONS FOR RESEARCH}

In general, more research on administrative internships is an area of need and promise. A logical extension of this paper's scholarly inquiry is the relationship of this internship model with professional success in educational leadership and student achievement. More specifically, is there a relationship between this internship model and principals' leadership practices? Are they more inclined to use heutagogy as a tool in professional development? Are principals who experience this internship model more inclined to use methods associated with distributed leadership?

\section{ACKNOWLEDGEMENTS}

The author would like to acknowledge Drs. Linda Angst-May and Keith Gurley for their input and research energies on the topic of these internships. My line of inquiry resulted from ideas from Dr. Joseph Murphy, Vanderbilt University, a scholar in educational leadership education, and a member of Dr. May's dissertation committee. Also, Deans Dianne Mark and Ed Jadallah gave us what we most needed- time to sort it out. A special thanks to the leadership of Horry, Marion, Dillon, Florence, and other regional school districts for allowing CCU's program to take root.

\section{ENDNOTES}

1. Throughout the paper, educational leadership and administration are used interchangeably

2. NCATE has subsequently merged with another accreditation body and is now called the Council for the Accreditation of Educator Preparation (CAEP)

3. In several places in the paper, Anglicized spellings are used when directly quoted from international sources.

\section{REFERENCES}

Anast-May, L., Buckner, B., \& Geer, G. (2010). Redesigning principal internships: Practicing principals' perspectives. International Journal of Educational Leadership Preparation, 6(1). Retrieved from http://www.ncpeapublications.org

Anderson, M. E. (1989). Training and selecting school leaders. In S.C. Smith \& P.K. Piele (eds.), School leadership (pp. 53-84). Eugene, OR: ERIC Clearinghouse on Educational Management.

Bass, G. (1990). The practitioner's role in preparing successful administrators. NASSP Bulletin, 74, $27-$ 30 .

Bhoyrub, J., Hurley, J., Neilson, G. R., Ramsay, M., \& Smith, M. (2010). Heutagogy: An alternative practice-based learning approach. Nursing Education in Practice, 10(6).

Black, W., \& Murtadha, K. (2007). Toward a signature pedagogy in educational leadership preparation and program assessment. Journal of Research on Leadership Education, 1(2), 1-29.

Blaschke L. M., \& Hase S. (2016). Heutagogy: A Holistic Framework for Creating Twenty-First-Century Self-determined Learners. In Gros B., Kinshuk, Maina M. (eds), The Future of Ubiquitous Learning. Lecture Notes in Educational Technology. Springer, Berlin, Heidelberg

Brown-Ferrigno, R., \& Muth, R. (2004). Leadership mentoring in clinical practice: Role socialization, professional development, and capacity building. Educational Administration Quarterly, 40(4), 468-494.

Brown, K., Squires, J., Connors-Tadros, L., \& Horowitz, M. (2014). What do we know about principal preparation, licensure requirements, and professional development for school leaders? CEELO Policy Report. New Brunswick, NJ: Center on Enhancing Early Learning Outcomes.

Chance, E. (1990, August 12-17). The administrative internship: Effective program characteristics. Paper presented at the Annual Meeting of the National Council of Professors of Educational Administration, Los Angeles, CA. 
Cordeiro, P. A., \& Smith-Sloan, E. (1995). Apprenticeships for Administrative Interns: Learning to talk like a principal. Paper presented at the Annual Meeting of the American Educational Research Association, San Francisco, CA.

Creighton, T. B. (2002). Towards a leadership practice field: An antidote for an ailing internship experience. AASA Professor, 25(3), 3-9.

Cunningham, W. (2007). A handbook for educational leadership interns: A right of passage. Boston, MA: Allyn \& Bacon.

Cunningham, W., \& Sherman, W. H. (2008). Effective internships: Building bridges between theory and practice, The Educational Forum, 4(72), 308-318. DOI: 10.1080/00131720802361936.

Daresh, G. (2004, October). Mentoring school leaders: Professional promise or predictable problems? Educational Administration Quarterly, 40(4) 495-517.

Davis, B., \& Sumara, D. (2008). Complexity as a theory of education. Transnational Curriculum Inquiry, 5(2). Retrieved January 5, 2018, from http://nital.library.ubc.ca/ojs/index.php/tci

Davis, S., Darling-Hammond, L., La Pointe, M., \& Meyerson, D. (2005). School leadership study: Developing successful principals (Review of Research). Stanford, CA: Stanford University, Stanford Educational Leadership Institute.

Darling-Hammond, L., La Pointe, M., Meyerson, D., Orr, M. T., \& Cohen, C. (2007). Preparing school leaders for a changing world: Lessons from exemplary leadership programs. Stanford, CA: Stanford University, Stanford Educational Leadership Institute.

Dubin, A. E. (1987). Administrative training: Socializing our school leaders. Planning and Changing, 18(1), 33-37.

Ehrich, L., Hansford, B., \& Tennannt, L. (2004). Formal mentoring programs in education and other professions: A review of the literature. Educational Administration Quarterly, 20(4).

Education Commission of the States. (2018, January 18). 50 state analysis. Retrieved from: $\mathrm{http}: / /$ ecs.force.com/mbdata/mbtab4ne?SID=a0i700000009va2\&Rep=MP

Educational Leadership Constituent Council's (ELCC). (2011). Educational leadership program recognition standards: Building level. Retrieved from: http://npbea.org/wpcontent/uploads/2018/01/ELCC-Building-Level-Standards-2011.pdf

Elmore, R. (2002). Building capacity to enhance learning: A conversation. Principal Leadership, 2(5), $39-43$.

Elmore, R. (2006). Breaking the cartel. Phi Delta Kappan, 87(7), 517. Academic OneFile. Web. 9 Feb. 2010.

Foster, L., \& Ward, K. (1998). The internship experience in the preparation of higher education administrators: A programmatic perspective. The AASA Professor, 222(2), 13-18.

Fry, B., Bottoms, G., \& O’Neill, K. (2005). Challenge to lead series: The principal internship: How can we get it right? Atlanta, GA: Southern Regional Education Board.

Fulmer, C., Muth, R., \& Reiter, K. F. (2004). Design elements for meaningful clinical practice experiences: The core of principal preparation programs. In C.S, Carr \& C.L. Fulmer (eds.), Educational leadership: Knowing the way, showing the way, going the way. The twelfth yearbook of the National Council of Professors of Educational Administration (pp.190-199). Lantham, MD: Scarecrow Press.

Gall, M. D., Borg, W. R., \& Gall, J. P. (1996). Educational research an introduction. White Plains, NY: Longman.

Garrison, D. R. (2006). Critical thinking and adult education: a conceptual model for developing critical thinking in adult learners. International Journal of Lifelong Education, 4(10), 287-303. DOI:10.1080/0260137910100403

Geer, G. (2018). Spadoni College of Education M.Ed. in educational leadership administrative Internship handbook For EDAD 694/695 Elementary Principal in Practice I and II EDAD 696/697 Secondary Principal in Practice I and II. 
Geer, G. (2011). Administrative Intern Survey (2011-2017). Retrieved January 30, 2018, from https://www.surveymonkey.com/collect/list?sm=R5X2OehxgRjDVnjM5hJOT9qplYTrln61dIMk 0FwHMIc 3D

Geer, G., Anast-May, L., \& Gurley, D. K. (2014, March). Interns' perceptions of administrative internships: Do principals provide internship activities in areas they deem important? The International Journal of Educational Leadership Preparation, 9(1). Retrieved from https://files.eric.ed.gov/fulltext/EJ1024113.pdf

Goldring, E., \& Sims, P. (2005). Modeling creative and courageous school leadership through districtcommunity-university partnerships. Educational Policy, 1(19), 223-249. DOI: $10.1177 / 0895904804270777$

Greenfield, T. B. (1975). Theory about organisations: a new perspective and its implications for schools. In M. Hughes (Ed.), Administering education: International challenge. Athlone Press: London.

Halverson, R., Grigg, J., Prichett, R., \& Thomas, C. (2007). The new instructional leadership: Creating data-driven instructional systems in schools. Journal of School Leadership, 17(2), 159-194.

Hase, S. (2002). Simplicity in complexity: Capable people and capable organisations need each other. Paper presented to Australian Vocational Education and Training Association Conference, Melbourne, Vic., April.

Hase, S., \& Kenyon, C. (2003, September). Heutagogy and developing capable people and capable workplaces: strategies for dealing with complexity. Proceedings of The Changing Face of Work and Learning conference, 25-27. University of Alberta, Alberta, Canada.

Hase, S. (2011). Learner defined curriculum: heutagogy and action learning in vocational training. Retrieved from https://www.researchgate.net/publication/254664050_Learner_defined_curriculum_heutagogy_a nd action learning in vocational training

Hase, S., \& Kenyon, C. (2007). Heutagogy: A child of complexity theory. Complexity. An International Journal of Complexity and Education, 4, 111-118.

Illinois State Board of Education. (2006, August). School leader preparation: A blueprint for change. Author: Springfield, IL.

Jackson, B., \& Kelley, C. (2002, April). Exceptional and innovative programs in educational leadership. Educational Administration Quarterly, 2(38), 192-212. DOI:10.1177/0013161X02382005

Kersten, T., White, D., \& Trybus, M. (2010). Administrative internships: Considering principals' voices from the field. International Journal of Leadership Preparation, 5(1), 1-12. Retrieved from http://ijelp.expressacademic.org

Knowles, M., \& Holton, E. (2005). The adult learner: The definitive classic in adult education and human resource development, 6th ed. Butterworth-San Diego, CA: Heineman.

Kolb, A. Y., \& Kolb, D. A. (2005). Learning Styles and Learning Spaces: Enhancing experiential learning in higher education. Academy of Management Learning \& Education, 4(2), 193-212.

Leithwood, K. (1995). Cognitive perspectives on school leadership. Journal of School Leadership, 5(2), $115-135$.

Lester, L. K., \& Bishop, L.K. (2000). Handbook of tests and measures in education and social sciences. Lanahan, MD: Rowman \& Littlefield Publishing.

Levine, A. (2005). Educating school leaders. The Education Schools Project Report \#1. Princeton, NJ: The Woodrow Wilson National Fellowship Foundation.

Martin, G. (2012) Four components of a successful school leader internship program. Larchmont, NY: Eye on Education.

Mason, E. J., \& Bramble, W. J. (1997). Research in education and the behavioral sciences: Concepts and methods. Dubuque, IA: Brown and Benchmark.

Mehta, J. (2013). From bureaucracy to profession: Remaking the educational sector for the twenty-first century. Harvard Educational Review, 83(3).

McCarthy, M. M., \& Kuh, G. D. (1997). Continuity and change: The educational leadership professoriate. Columbus, MO: UCEA.

52 Journal of Higher Education Theory and Practice Vol. 20(1) 2020 
McKerrow, K. (1998). Administrative internships: Quality or quantity? Journal of School Leadership, 8, 171-187.

Milstein, M. M. (1990). Rethinking the clinical aspects in administrative preparation: From theory to practice. In S.L. Jacobson \& J. Conway (eds.), Educational leadership in an age of reform (pp. 119-130). New York: Longman.

Milstein, M., \& Krueger, J. (1997). Improving educational administration preparation programs: What we have learned over the past decade. Peabody Journal of Education, 72(2), 100-116.

Milstein, M., Bobroff, B., \& Restine, L. N. (1991). Internship programs in educational administration. New York: Teachers College Press.

Mirici, P. S., \& Hensley, P. A. (2010). Leading for innovative practice: Melding theories of organizational change, adult learning, and conditions of learning. CAEPA Education Leadership and Administration, 22.

Morrison, K. (2002). School leadership and complexity theory. New York: RoutledgeFalmer.

Morrison, K. (2010). Complexity Theory, school leadership, and management: Questions for theory and practice. Education Management \& Leadership, 38(3), 374-393.

Murphy, J. (1992). The landscape of leadership preparation: Reframing the education of school administrators. Newbury Park, CA: Corwin Press.

Murphy, J. (2006). Preparing school leaders: Defining a research and action agenda. Lanham, MD: Rowman \& Littlefield Education.

Murphy, J., \& Hallinger, P. (1987). New directions in the professional development of school administrators: A synthesis and suggestions for improvement. Approaches to administrative training in education, Albany, NY: SUNY Press, 245-273.

Murphy, J., Moorman, H., \& McCarthy, M. (2008). Framework for rebuilding initial certification and preparation programs in educational leadership: Lessons from whole-state reform initiatives. Teacher's College Record, 10(110), 2172-2203.

Murphy, J., \& Seashore L. K. (1999). Handbook of research on educational administration. San Francisco: Jossey-Bass.

NGA Center for Best Practices. (2003, September 12). Issue brief: Improving teaching and learning by improving school leadership. Retrieved from https://www.nga.org/files/live/sites/NGA/files/pdf/091203LEADERSHIP.pdf

National Policy Board for Educational Administration. (2002). Standards for advanced programs in educational leadership for principals, superintendents, curriculum directors and supervisors: An agenda for reform. Charlottesville: University of Virginia.

Orr, M. T., \& Orphanos, S. (2010, November). How graduate-level preparation influences the effectiveness of school leaders: A comparison of the outcomes of exemplary conventional leadership programs for principals. Education Administration Quarterly. DOI: 10.1177/0011000010378610

Orr, M. T. (2010). Pipeline to preparation: Graduates' experiences in, through, beyond leadership preparation. Education Administration Quarterly. DOI: 10.1177/0011000010378612

Pohland, P. A., \& Carlson, L. T. (1993). Program reform in educational administration, 34(3), 4-9. State College: Pennsylvania University, University Council for Educational Administration.

Restine, L., Milstein, M., \& Broboff, B. (1989, October). Selection of the knowledge base for administrative internship programs. Paper presented at the annual meeting of the University Council for Educational Administration, Scottsdale, AZ.

Sherman, W. H. (2005). Preserving the status quo or renegotiating leadership: Women's experiences with a district-based aspiring leaders program. Educational Administration Quarterly, 41(5), 707-740.

Skalski, J., Lohman, M., Szcepanik, J., Baratta, A., Bacilious, Z., \& Schulte, S. (1987). Administrative internships. In annual meeting of the American Educational Research Association, Washington, DC.

Senge, P. (2006). The fifth discipline: The art \& practice of the learning organization. New York: Doubleday. 
Snowden, M. (2015, March 12). Self-Determined learning (heutagogy) and the flexible curriculum. In UALL Annual Conference 2015: Making the Lifelong Learning University a Reality. University of Strathclyde, Glasgow.

Southern Regional Education Board. (2005). Good principals are the key to successful schools: Six strategies to prepare more good principals. Atlanta, GA: Author.

Southern Regional Education Board. (2005). The principal internship: How do we get it right? Atlanta, GA.: Author. Retrieved from http://www.sreb.org/programs/hstw/publications/pubs/05V02PrincipalInternship.asp

Young, M. D., \& Mawhinney, H. (Eds.). (2012). The research base supporting the ELCC standards. Charlottesville, VA: University Council for Educational Administration.

Wagner, T., Kegan, R., Lahey, L., Lemons, R., Garnier, J., Helsing, D., . . . Rasmussen H. T. (2010). Change leadership: A practical guide for transforming our schools. San Francisco: Jossey-Bass.

Weick, K. (1976). Educational organizations as loosely coupled systems. Administrative Science Quarterly, 83(1), 1-19.

White, E., \& Crow, G. M. (1993, April). Rites of passage: The role perceptions of interns in the preparation for principalship. Paper presented at the annual meeting American Educational Research Association, Atlanta, GA. 